\title{
Tra Intelligenza Artificiale e H-BIM per la descrizione semantica dei beni culturali: la Certosa di Pisa
}

\author{
Valeria Croce \\ Gabriella Caroti \\ Livio De Luca \\ Andrea Piemonte \\ Philippe Véron \\ Marco Giorgio Bevilacqua
}

Abstract

L'applicazione dell'Intelligenza Artificiale (IA) ai beni architettonici introduce promettenti evoluzioni nel settore del Disegno: tecniche più automatizzate di segmentazione semantica possono essere estese al modello digitale e numerico per l'interpretazione dei dati di rilievo e per la conseguente ricostruzione di rappresentazioni 3D concettuali e parametriche.

Nuovi sistemi per la descrizione e la classificazione di dati 3D sono effettivamente sempre più richiesti, anche in vista dell'ottimizzazione di processi del tipo Scan-to-BIM. In questo contesto, il presente contributo illustra un approccio metodologico semi-automatico volto alla costruzione di rappresentazioni semanticamente ricche e intelligibili a partire da dati di rilievo. Tale approccio si basa su due nuclei fondanti: in primis, la classificazione e successiva propagazione di tipologie architettoniche, attraverso algoritmi di IA applicati alla nuvola di punti; quindi, la ricostruzione in ambiente Building Information Modelling (BIM) delle classi di elementi individuate tramite meccanismi di trasmissione delle informazioni e linguaggi di programmazioni visuale. La metodologia proposta è studiata in riferimento a casi studio rappresentativi relativi ad alcuni ambienti della Certosa Monumentale di Pisa.

Parole chiave

classificazione semantica, intelligenza artificiale, H-BIM, patrimonio architettonico, nuvola di punti.

Data acquisition

Semantic segmentation via Al

H-BIM model reconstruction

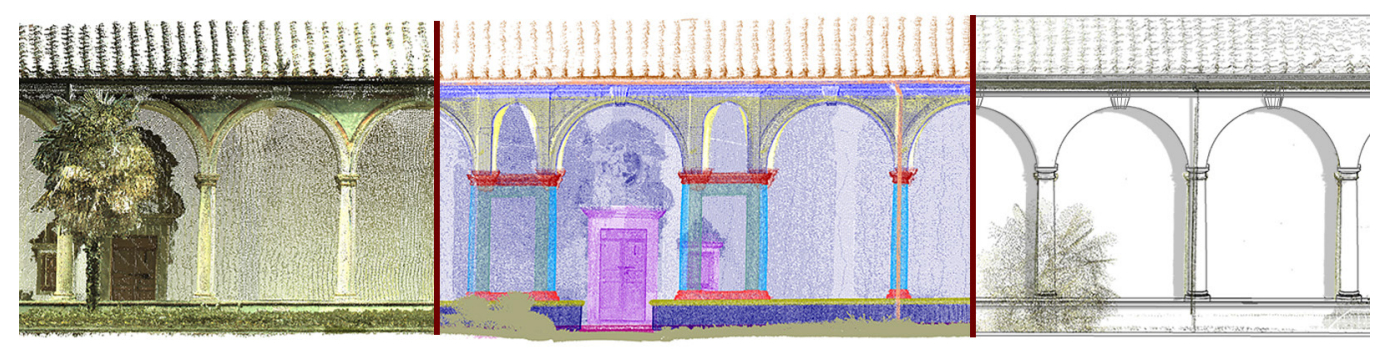




\section{Introduzione}

Nelle discipline del disegno, il rilievo 3D per la documentazione digitale dei beni culturali è oggi sempre più diffuso. L'evoluzione di tecniche di acquisizione come il laser scanner e la fotogrammetria ha permesso un impiego sempre maggiore di nuvole di punti e mesh quali dati di partenza per applicazioni di conservazione, valorizzazione e disseminazione del patrimonio storico e architettonico. Così, ad esempio, i moderni processi Scan-to-BIM si basano sull'utilizzo di dati 3D per la creazione di modelli digitali informativi.

Seppure le nuvole di punti rappresentino un dato di input metricamente controllabile, la ricostruzione di modelli parametrici del tipo H-BIM (Heritage-Building Information Modelling) a partire da tali dati rappresenta oggi un procedimento lungo e laborioso, che richiede procedure complesse di interpretazione, riconoscimento e successiva modellazione degli elementi 3D e che impone quindi un consistente intervento umano.

In questo scenario, lo sviluppo nell'utilizzo di algoritmi di IA ha aperto la strada a sistemi più automatizzati per la segmentazione semantica di dati 3D, quest'ultima intesa come la suddivisione del dato di rilievo in gruppi di elementi tipologici (ad esempio: muro, solaio, volta, colonna, copertura...), individuati sulla base di caratteristiche geometriche e colorimetriche (feature) comuni.

L'automazione dell'operazione di segmentazione semantica consentirebbe di caratterizzare e descrivere la scena rilevata, inserendo degli attributi semantici, cioè legati alla conoscenza diretta del bene. Nell'affrontare questo tema, obiettivo del presente lavoro è illustrare un approccio semi-automatico per la ricostruzione di rappresentazioni intelligibili a partire dal rilievo 3D, anche in vista di una ottimizzazione dei processi del tipo Scan-to-BIM. La metodologia proposta si applica al caso di edifici che presentino tipologie architettoniche ricorrenti e si basa su (fig. I):

-Tecniche semi-automatiche di identificazione, classificazione e successiva propagazione di elementi tipologici, attraverso algoritmi di IA;

- Una ricostruzione 3D delle geometrie individuate, attraverso linguaggi di programmazione visuale implementati in piattaforme BIM.

Fig. I. Workflow dell'approposto. proccio metodologico
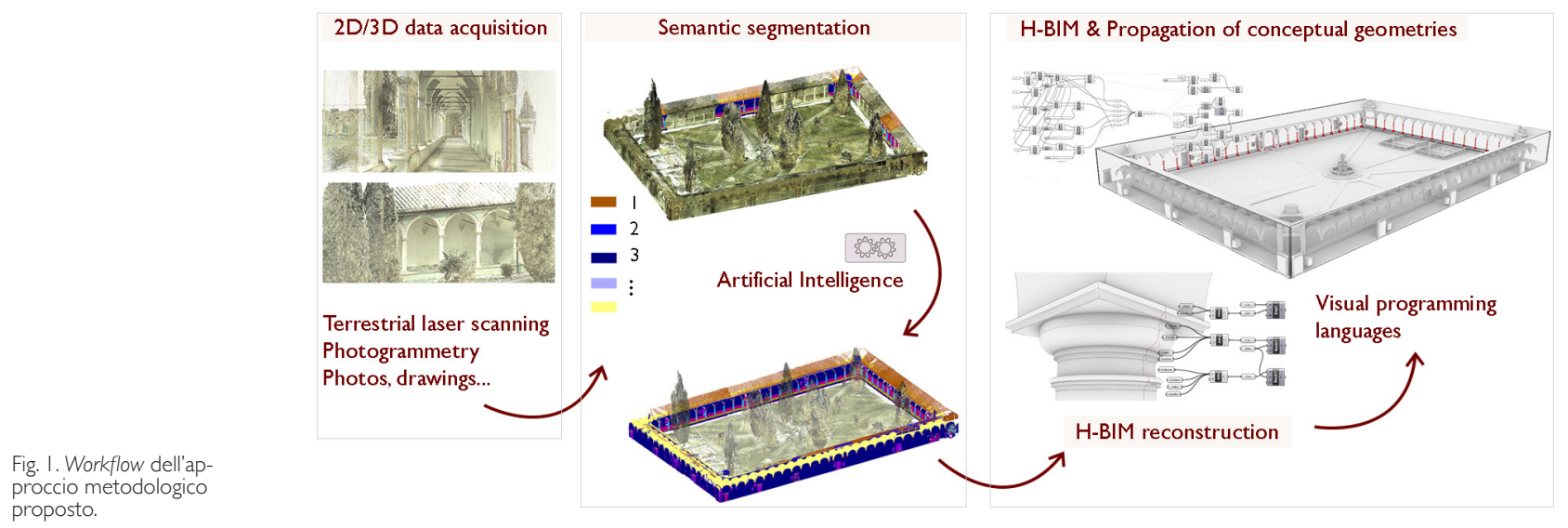

\section{Stato dell'arte}

I modelli digitali informativi dei beni architettonici costituiscono uno strumento fondamentale di supporto alle attività di conservazione e tutela dei beni architettonici. Attraverso il meccanismo dell'annotazione semantica [Croce et al. 2020], i sistemi H-BIM consentono di collegare alla rappresentazione geometrica degli attributi descrittivi [López et al. 2018, Murphy et al. 2009], che possono riguardare, ad esempio, la mappatura dei materiali, del degrado [Bacci et al.20 I9], di superfici affrescate [Robleda-Prieto et al. 20 I6], le relazioni tra le diverse parti che compongono un edificio [De Luca et al. 2007] o ancora il collegamento a risorse documentarie e informazioni storiche [Roussel et al. 2019]. 
II processo di documentazione digitale 3D del patrimonio architettonico si articola nelle rispettive fasi di [Hichri et al. 2013]: a) acquisizione dei dati di rilievo, b) segmentazione semantica, e c) costruzione del modello informativo in ambiente BIM. Di queste, la segmentazione semantica è la fase più lunga e meno automatizzata: si richiede ai disegnatori di interpretare una grande mole di dati non strutturati, per individuare, riconoscere e quindi ricostruire manualmente, a partire dalla nuvola di punti, le diverse geometrie di un edificio. L'intervento umano necessario è pertanto considerevole, e il procedimento può portare alla perdita di informazioni significative [Macher et al. 2017, Rocha et al. 2020; 20 I7; Rocha et al. 2020].

Nell'ottica di migliorare questa fase interpretativa del rilievo, rendendo il processo più oggettivo e ripetibile, sono state sperimentate tecniche più automatizzate di segmentazione semantica, basate sul Machine Learning (ML) e sul Deep Learning (DL), sottocategorie dell'IA. Nel ML supervisionato, si parte dall'annotazione manuale di una porzione della nuvola di punti e si identificano delle feature, che consentono di differenziare in maniera opportuna classi di elementi sulla base delle loro proprietà, ad esempio geometriche e colorimetriche. Quindi, si addestra il sistema a classificare nuovi dati sulla base delle feature individuate. Nel caso del DL, a partire da una mole più elevati di dati annotati forniti, è il sistema stesso che identifica le caratteristiche distintive adeguate, tramite reti neurali artificiali multi-layer.

Su un algoritmo di ML supervisionato, il Random Forest (RF), si sono basati alcuni studi recenti [Grilli et al. 20 I9;Teruggi et al. 2020], che hanno mostrato come la classificazione delle nuvole di punti 3D basata sulla scelta di feature geometriche ad hoc possa essere applicata efficacemente anche al caso dei beni culturali, per distinguere elementi architettonici ricorrenti.

Per quanto riguarda il DL, invece, le applicazioni ai beni culturali restano a oggi molto limitate [Matrone et al. 2020a], da una parte a causa della difficoltà di estendere il riconoscimento di classi di elementi a dataset diversi, vista la complessità morfologica e tipologica di ogni edificio storico, e dall'altra per via della scarsa disponibilità di una mole sufficiente di dati annotati per l'allenamento dei modelli predittivi [Matrone et al. 2020b].

Gli studi di segmentazione tramite ML risultano per questo i più promettenti, ma manca in generale una maggiore attenzione alle effettive possibilità di utilizzo del dato 3D segmentato, ad esempio, per arricchire modelli H-BIM; inserendosi in questo contesto, il presente studio mira ad approfondire il momento di passaggio dalla nuvola di punti semantica alla rappresentazione parametrica del tipo H-BIM.
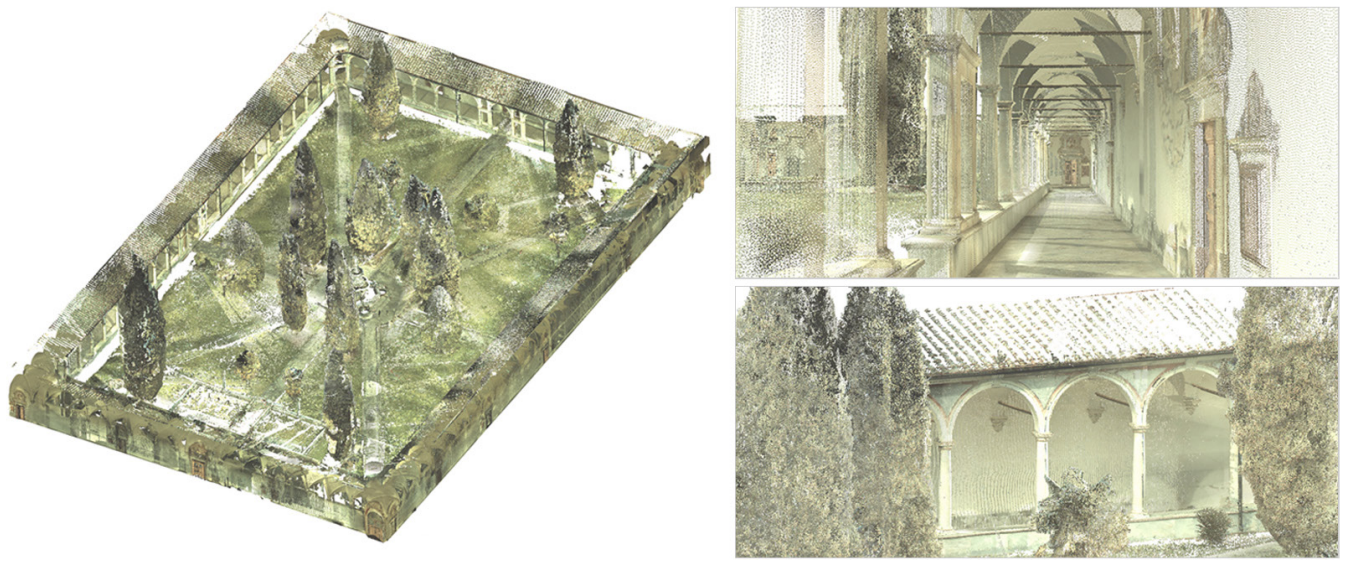

\section{Il caso studio della Certosa di Calci}

Fondata nel 1366 su iniziativa di alcune famiglie nobiliari pisane, la Certosa di Pisa a Calci rappresenta uno dei più importanti complessi monastici della Toscana. L'assetto attuale, frutto di continui interventi di ampliamento e ristrutturazione, risponde agli schemi tipologici della regola certosina, in cui vita eremitica e cenobitica sono fuse armonicamente. Case basse, corte 


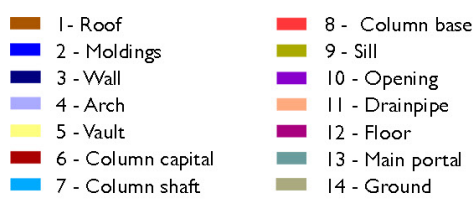

Fig. 3. Classi di elementi individuate a partire dal dato di rilievo. II training set.

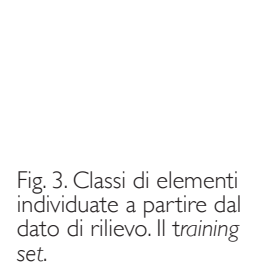

Fig. 4. Feature geometriche: verticalità.

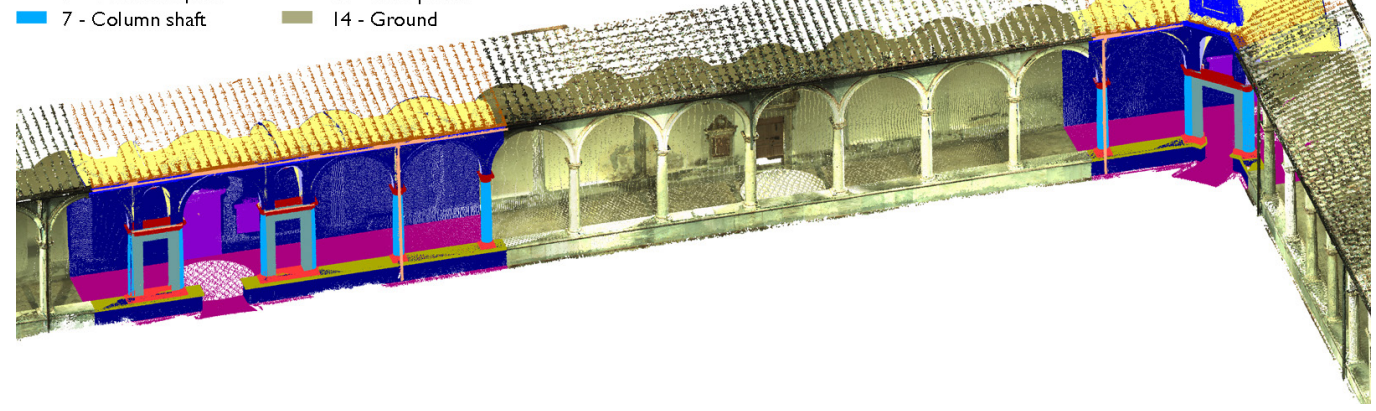

d'onore, chiesa, cenobio definiscono una progressiva ascesa verso il desertum e il cuore del complesso: il chiostro dei Padri.

La costruzione del chiostro risale al 1375 , con la realizzazione della prima cella destinata al Priore. I lavori proseguono probabilmente fino al I 384. Nel XVII secolo, si registrano importanti lavori di ammodernamento, dovuti principalmente alla necessità di sanare gli spazi delle celle da fenomeni di umidità. Gli interventi contemplano un innalzamento dei pavimenti delle celle e del portico, oltre a un generale riammodernamento stilistico del chiostro [Manghi 1910].

Ottanta colonne di marmo si dispongono lungo il perimetro del chiostro a sostenere il sistema di volte a crociera dell'ambulacro; quattro serliane interrompono il ritmo delle colonne marcando i due assi principali del sistema compositivo; dipinti a secco raffiguranti scene sacre e iconografie di santi decorano le porte di accesso alle celle; al centro del chiostro, la fontana monumentale in pietra riccamente decorata completa l'assetto scenografico dello spazio.

Da allora, il chiostro non ha subito successive modifiche sostanziali, nemmeno durante i grandi lavori di ristrutturazione promossi dal priore Maggi durante la fine del XVIII secolo, lavori ai quali sostanzialmente si deve l'assetto attuale dell'intero complesso.

Sul finire del XIX secolo e fino alla metà del XX secolo, si registrano infatti solo interventi di coloritura delle superfici, determinati dalla necessità di uniformare l'aspetto cromatico degli intonaci e, successivamente, per ragioni di manutenzione ordinaria [Benassi 2005].

Sciolta dall'ordine generale di Grenoble, nel 1962 la comunità religiosa lascia la certosa, che viene gradualmente destinata ad attività museali. Dal 1972, infatti, il complesso ospita il Museo Nazionale della Certosa Monumentale di Calci, sotto il controllo del Ministero dei Beni e delle Attività Culturali e del Turismo - MiBACT, e, dal 1978, il Museo di Storia Naturale dell'Università di Pisa.

A partire dal 2018 l'Università di Pisa ha finanziato un progetto di ricerca multidisciplinare volto alla conservazione, restauro e valorizzazione dell'intero complesso; la ricerca qui proposta, rientra all'interno di queste attività (fig. 2).

\section{Verticality $(r=0.3 \mathrm{~m})$}
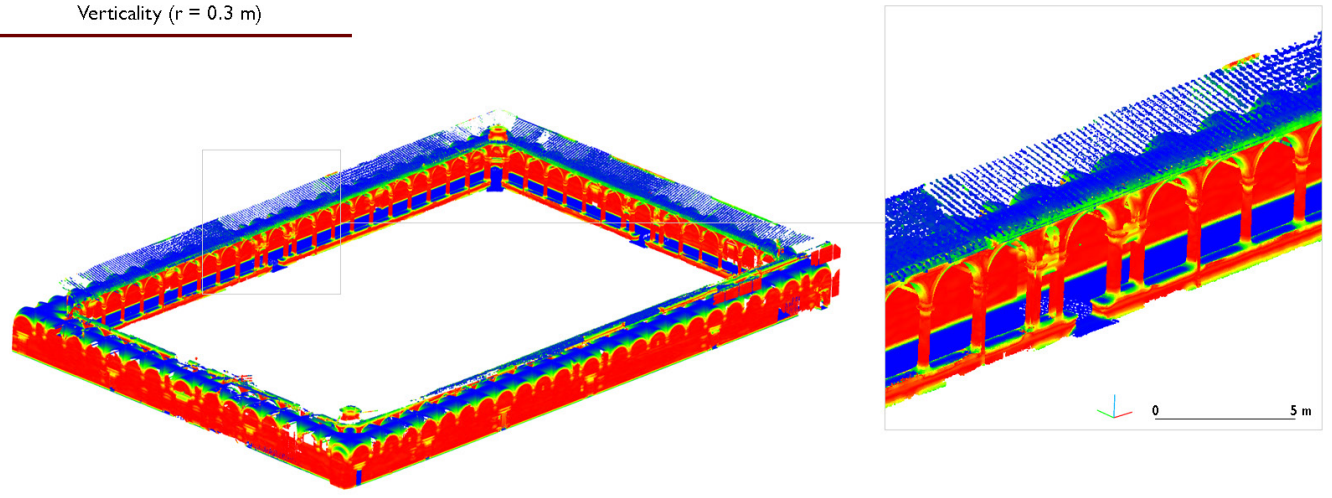
Fig. 5. Esempio di feature geometriche: normal change rate e surface variation.

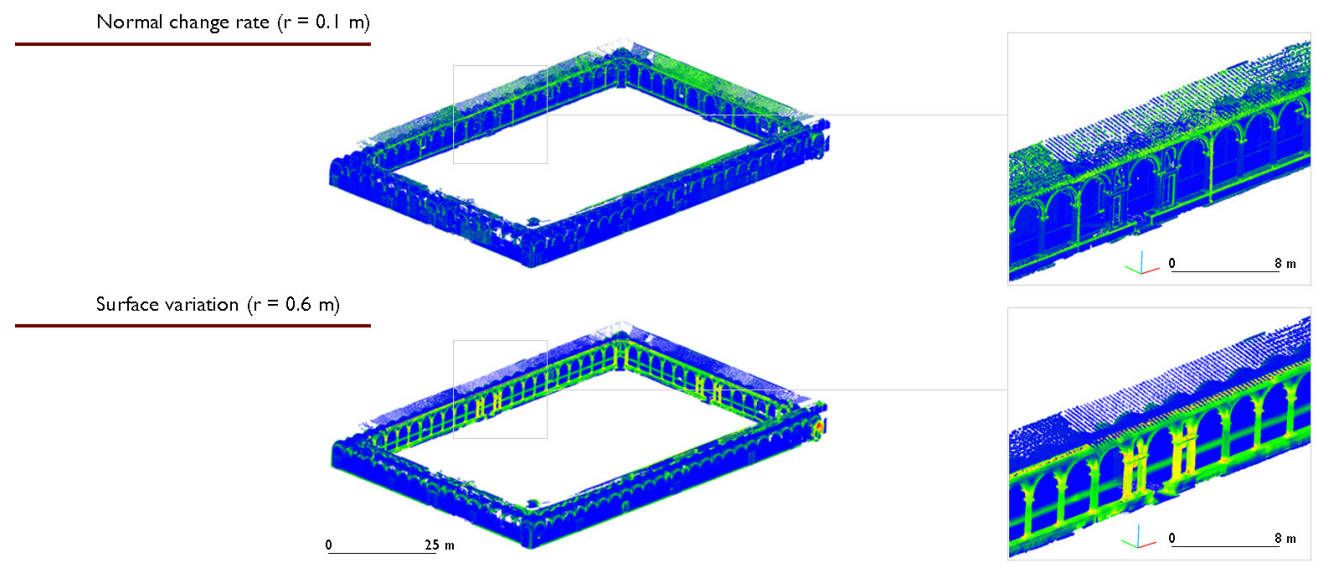

Metodologia: dalla nuvola di punti semantica all'H-BIM

Il presente lavoro scaturisce dalla considerazione che è possibile riconoscere, nella complessità morfologica e costruttiva degli edifici storici, forme e tipologie architettoniche ricorrenti. Questo consente di distinguerle e, di conseguenza, rappresentarle, ricostruendo la grammatica delle loro forme (shape grammar). Il procedimento di 'segmentazione semantica', in effetti, è lo stesso che ha portato Vitruvio e i grandi trattatisti a studiare e tramandare le caratteristiche proporzionali degli ordini architettonici, codificando linguaggi e modelli dell'architettura classica.

Nell'approccio metodologico proposto:

a) dapprima, si esegue la segmentazione semantica del set di dati 3D, tramite algoritmi di apprendimento supervisionato derivati dall'IA;

b) quindi, la nuvola di punti contenente la suddivisione in classi di elementi tipologici (muro, colonna, solaio, copertura...) è sfruttata per generare e organizzare in maniera più efficace modelli $\mathrm{H}$-BIM.

Nella prima fase (a), si annota una parte ridotta della nuvola di punti, identificando le classi. Questa operazione, insieme alla scelta di opportune feature, consente di fornire al sistema di apprendimento un numero adeguato di esempi 'annotati' per classificare correttamente la parte restante del dataset.

Nel ML supervisionato, le feature sono identificate e scelte di volta in volta in relazione al caso studio, e possono essere:

- colorimetriche, ovvero relative al dato di colore associato a ogni punto 3D;

- geometriche, che descrivono la disposizione spaziale reciproca dei punti della nuvola.

Ad esempio, in un certo intorno locale dei punti 3D, si possono estrarre caratteristiche geometriche come la linearità, la planarità, la sfericità, la variazione superficiale e così via [Croce et al. 2021; Grilli, Farella et al. 2019].

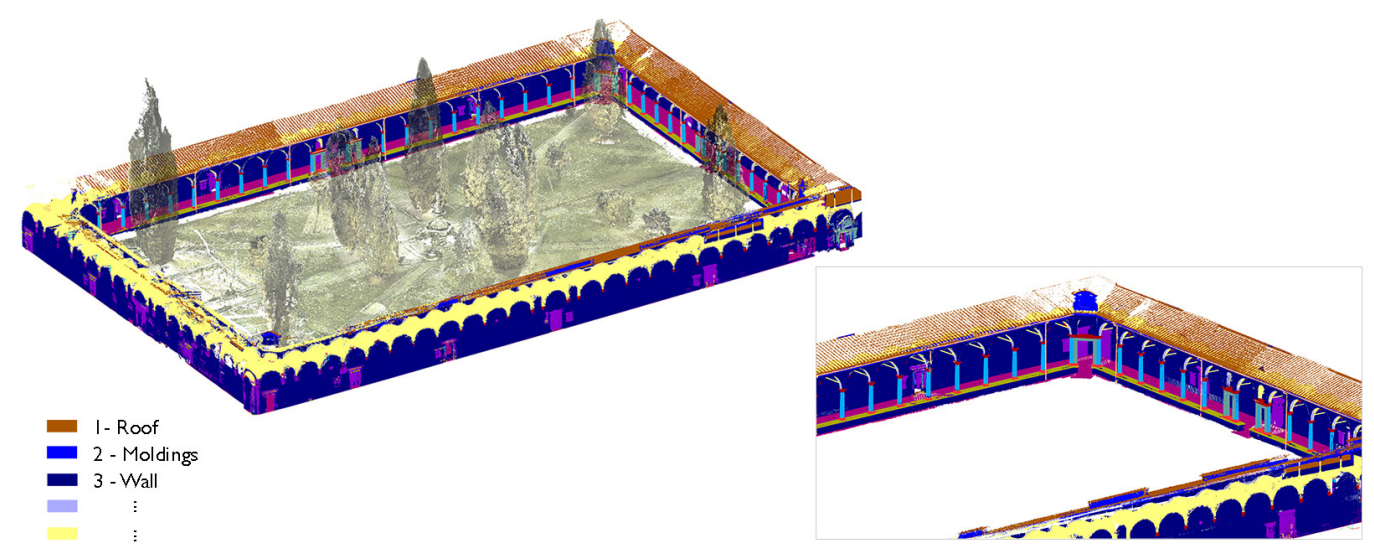


Fig. 7. Importazione della nuvola di punti segmentata. classe 'volte'.
Sulla base di questi dati di input, viene costruito il modello predittivo, che consente di associare un'etichetta semantica (la label) alla restante porzione della nuvola di punti, non precedentemente annotata.

Tale procedura viene eseguita attraverso costruzione di un classificatore RF e porta ad avere in ultima istanza un dato 3D semanticamente ricco, in cui è possibile distinguere, riconoscere, e di conseguenza anche isolare, tutti gli elementi architettonici presenti. Per la valutazione del modello di ML ottenuto, infine, si confrontano le previsioni restituite dal classificatore con la classe effettiva di destinazione.

La segmentazione semantica tramite IA consente di suddividere di volta in volta il dato iniziale di rilievo secondo la logica di ciò che vi è rappresentato; in altre parole, è possibile trattare ciascuna classe di elementi in maniera separata. Per la seconda fase (b), si sfrutta la nuvola di punti semanticamente annotata per ricostruire un modello H-BIM composto da 'famiglie' di elementi parametrici, create classe per classe.

Questo avviene definendo delle geometrie concettuali a priori per ciascuna categoria di elementi, sulla base di regole proporzionali e costruttive derivate delle fonti storiche. Si identificano cioè le entità atomiche e si formalizzano le primitive architettoniche alla base della rappresentazione [De Luca et al. 2007], ricostruendo la natura geometrica degli elementi e interpretando per essi la forma originaria di progetto. Così, si individua e si modella per ciascuna classe (o 'famiglia parametrica') una geometria ideale di riferimento.

Alla fine del processo, le tecniche di visual programming consentono la propagazione e il confronto dimensionale di elementi ripetitivi.
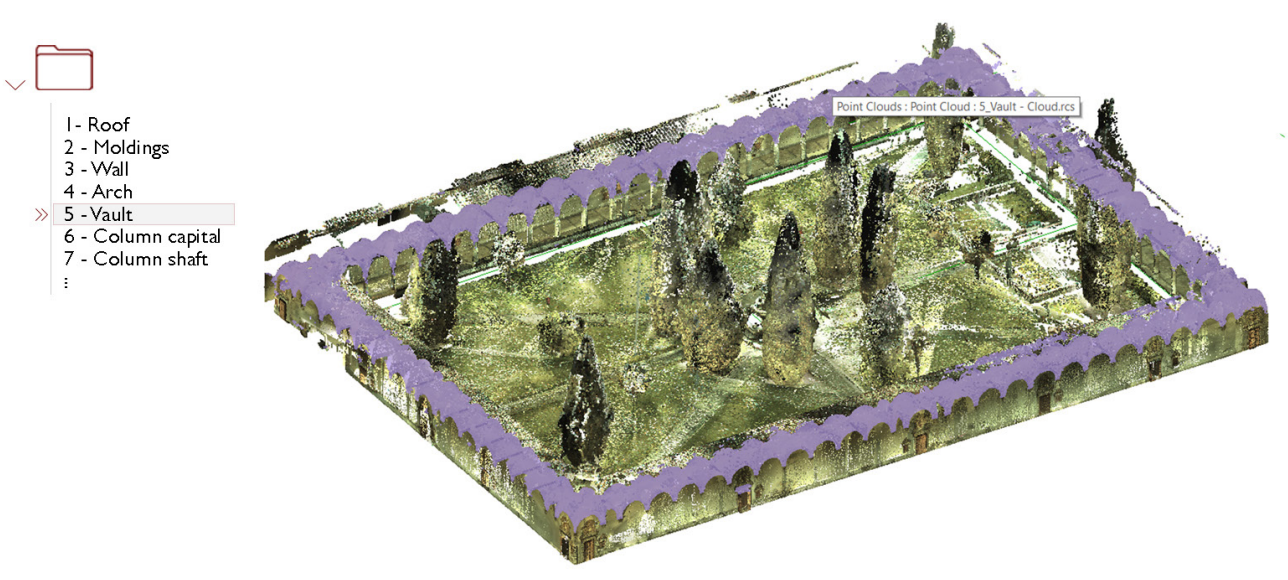

\section{Risultati}

II patrimonio delle certose è di fondamentale importanza per le prime significative sperimentazioni della metodologia proposta. Per esso, infatti, la collocazione spaziale degli ambienti segue le pratiche e gli usi dei monaci certosini, e c'è per questo una grande ripetizione di elementi archetipici: il chiostro principale, i chiostri minori, le celle dei padri e la chiesa, con portici, gallerie, volte affrescate.

Nel caso del Chiostro Grande, a partire dalla nuvola di punti iniziale, sono manualmente annotate su una porzione ridotta le 14 classi di elementi di fig. 3, riconosciute a partire da trattati di architettura. Quindi, sono estratte e selezionate le feature geometriche (figg. 4, 5). L'annotazione manuale del cosiddetto training set, insieme alla selezione delle feature, permette di allenare un classificatore RF, che estende la segmentazione semantica all'intero dataset del chiostro. II risultato della classificazione è illustrato in fig. 6 e costituisce la base per la successiva costruzione del modello H-BIM. La nuvola di punti, segmentata e isolata per classi di elementi, è dunque trasferita in ambiente di modellazione H-BIM (fig. 7).

Qui, per ciascuna classe, la ricostruzione della forma parametrica concettuale segue l'approccio di formalizzazione proposto da [De Luca et al. 2007], che si basa su: interpretazione 
Fig. 8. Costruzione delle modanature su atomi geometrici a partire De Luca et al. 2007.

Fig. 9. Costruzione geometrica di un capitello con il linguaggio di programmazione visuale.

Fig. 10. Modello H-BIM costruito tramite propagazione di geometrie concettuali. Esempio de fusto della colonna.

della conoscenza relativa alla forma, individuazione dei metodi di modellazione e, infine, identificazione delle relazioni tra le parti costitutive della forma $($ figg. 8, 9).

Una volta ricomposta una geometria concettuale a partire dal rilievo, questa è propagata alle altre parti della nuvola di punti, che sono state identificate come appartenenti alla stessa classe semantica (fig. 9). L'approccio di ricostruzione e propagazione delle geometrie 3D sfrutta i linguaggi di programmazione visuale e, se ripetuto per ciascuna categoria, consente di ottenere alla fine del processo un modello virtuale parametrico, un digital twin che può essere arricchito di informazioni su materiali, interventi restaurativi e di consolidamento, struttura portante e analisi termiche (figg. I0, I I).
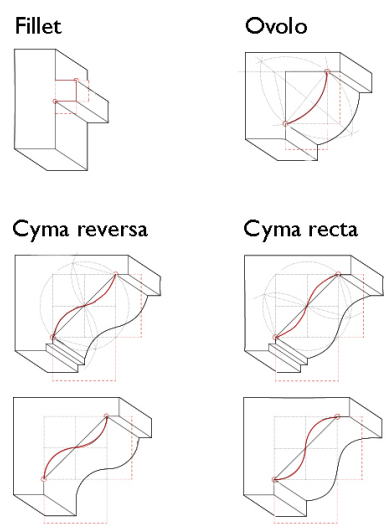
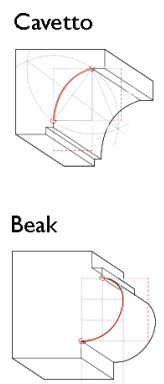

Scotia
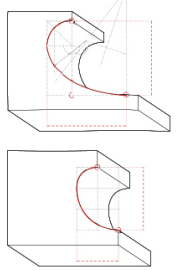
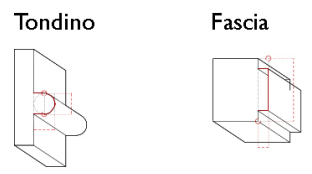

Scotia (Vignola)

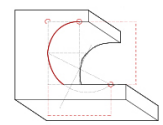

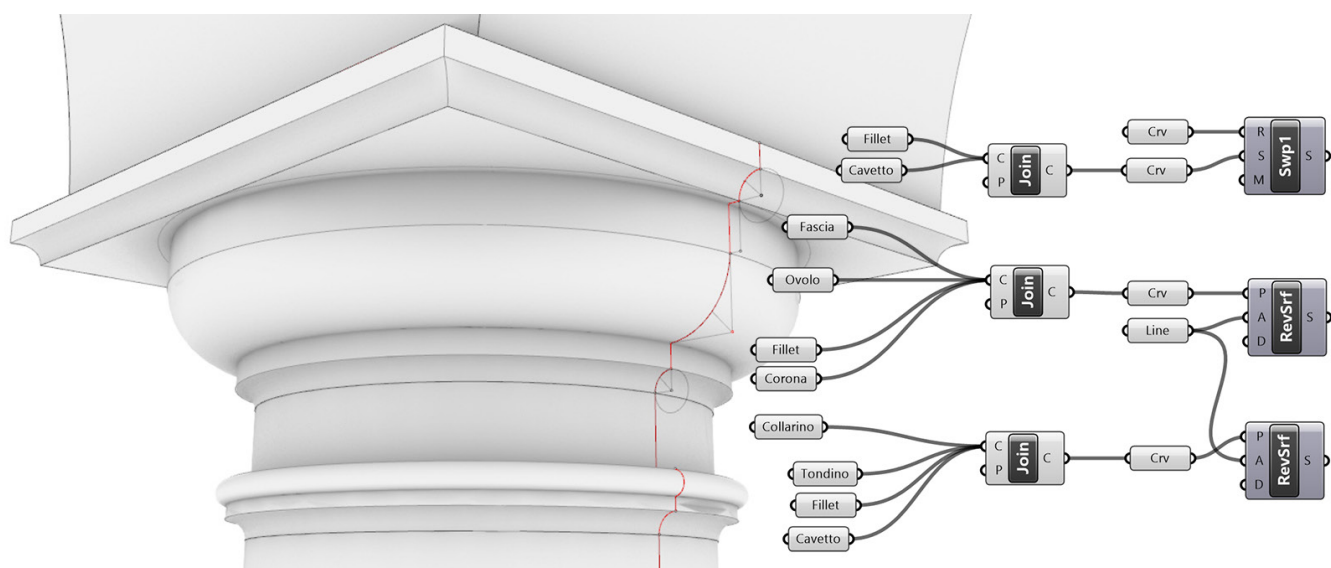

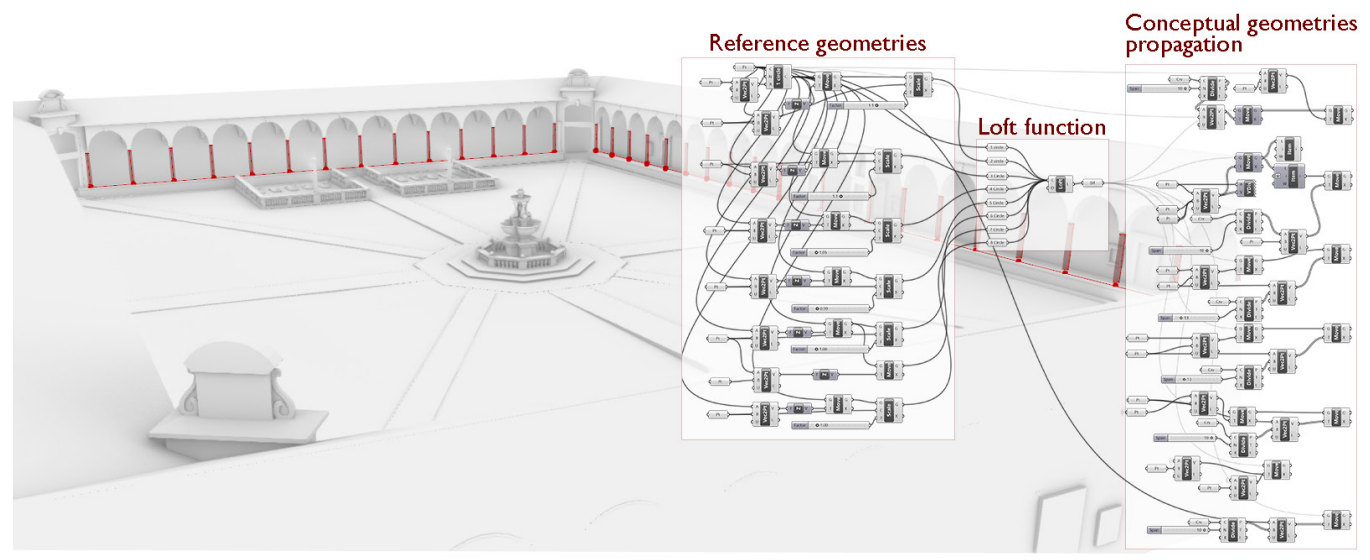




\section{Conclusioni}

Le tecniche di IA applicate ai beni culturali aprono la strada a nuovi modi di interpretare, conoscere e rappresentare il dato geometrico, 2D o 3D, ottenuto dal rilievo. Si acquisisce così un più diretto collegamento, formale e 'ontologico', tra dati metrici e modelli digitali integrati, come quelli del tipo H-BIM, per la documentazione del costruito storico.

Ulteriori sperimentazioni vanno nella direzione del miglioramento del processo di costruzione della replica digitale e dell'estensione della metodologia proposta ad altri dataset. Così, si prevede di applicare l'approccio presentato a vari casi studio, relativi a edifici storici e beni culturali che siano stati costruiti in epoche diverse, o che si presentino in condizioni differenti di conservazione, per valutare le specificità di ogni nuovo contesto.

Infine, l'applicazione dell'IA per la mappatura semantica di elementi di degrado o per la restituzione materica delle superfici, a partire da dati di rilievo 2D/3D, è a oggi studiata come sviluppo ulteriore del presente lavoro.

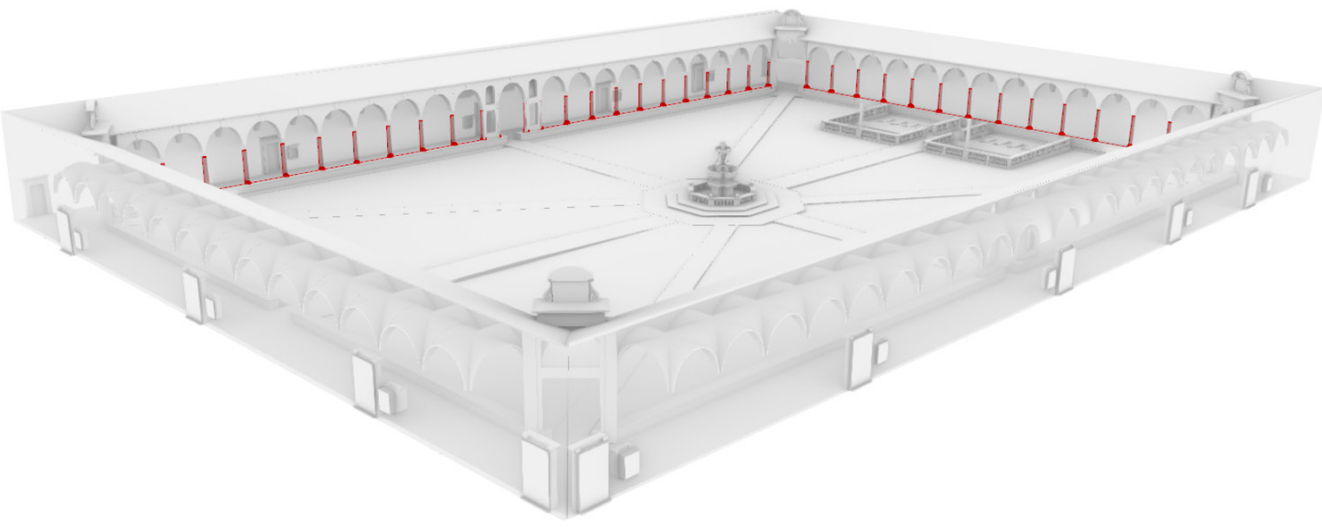

\section{Ringraziamenti}

II presente studio rientra nell'ambito del progetto Studi conoscitivi e ricerche per la conservazione e la valorizzazione del Complesso della Certosa di Calci e dei suoi Poli Museali, finanziato dall'Università di Pisa. Si ringraziano pertanto tutti i ricercatori e collaboratori coinvolti nel progetto. La ricerca è in parte finanziata dall'Université Franco-Italienne, nell'ambito del progetto Vinci 2019 - Contributi di mobilità per tesi di dottorato in co-tutela, che promuove la collaborazione tra unità di ricerca italiane e francesi.

\section{Riferimenti bibliografici}

Bacci G. et al. (2019). HBIM methodologies for the architectural restoration. The case of the ex-church of San Quirico all'Olivo in Lucca, Tuscany. In ISPRS - International Archives of the Photogrammetry, Remote Sensing and Spatial Information Sciences, XLII-2I WII, pp. $121-126$.

Benassi L. (2005). I/ chiostro grande della Certosa di Calci: storia, paesaggio, architettura. Pisa: Primula Multimedia, 2005, pp. 25-29.

Croce V. et al. (2020). Semantic annotations on heritage models: 2D/3D approaches and future research challenges. In ISPRS International Archives of the Photogrammetry, Remote Sensing and Spatial Information Sciences, XLIII-B2-2020, pp. 829-836.

Croce V. et al. (202I). From the Semantic Point Cloud to Heritage-Building Information Modeling: A Semiautomatic Approach Exploiting Machine Learning. In Remote Sensing, I3 (3), p. 46 I.

De Luca L.,Véron P., Florenzano M. (2007). A generic formalism for the semantic modeling and representation of architectural elements. In The Visual Computer, 23 (3), pp. I8I-205.

Grilli E. et al. (2019). Geometric features analysis for the classification of Cultural Heritage point clouds. In ISPRS - International Archives of the Photogrammetry, Remote Sensing and Spatial Information Sciences, XLII-2N I 5, pp. 54I-548. 
Grilli E., Özdemir E., Remondino F. (2019). Application of machine and deep learning strategies for the classification of heritage point clouds. In ISPRS - International Archives of the Photogrammetry, Remote Sensing and Spatial Information Sciences, XLII-4/ WI8, pp. 447-454.

Hichri N. et al. (20 I3). From point cloud to BIM: A survey of existing approaches. In ISPRS - International Archives of the Photogrammetry, Remote Sensing and Spatial Information Sciences, XL-5/W2, pp. 343-348.

López F. et al. (20 I8). A Review of Heritage Building Information Modeling (H-BIM). In Multimodal Technologies and Interaction, 2 (2), p. 21.

Macher H., Landes T., Grussenmeyer P. (2017). From Point Clouds to Building Information Models: 3D Semi-Automatic Reconstruction of Indoors of Existing Buildings. In Applied Sciences, 7 ( I0), p. 1030.

Manghi A. (19|0). II Gran Chiostro della Certosa di Pisa. Pisa: Mariotti.

Matrone F., Grilli E. et al. (2020). Comparing Machine and Deep Learning Methods for Large 3D Heritage Semantic Segmentation. In ISPRS International Journal of Geo-Information, 9 (9), p. 535.

Matrone F., Lingua A. et al. (2020). A benchmark for large-scale heritage point cloud semantic segmentation. In ISPRS - International Archives of the Photogrammetry, Remote Sensing and Spatial Information Sciences, XLIII-B2-2020, pp. I 4I 9 - I 426.

Murphy M., McGovern E., Pavia S. (2009). Historic building information modelling (HBIM). In ISPRS - International Archives of the Photogrammetry, Remote Sensing and Spatial Information Sciences, 27 (4), pp. 3 I I-327.

Robleda P. G. et al. (20 I 6). Computational vision in UV-mapping of textured meshes coming from photogrammetric recovery: Unwrapping frescoed vaults. In ISPRS - International Archives of the Photogrammetry, Remote Sensing and Spatial Information Sciences, XLI-B5, pp. 39I-398.

Rocha G. et al. (2020). A Scan-to-BIM Methodology Applied to Heritage Buildings. In Heritage, 3 ( I), pp. 47-67.

Roussel R. et al. (2019). A digital diagnosis for the "autumn" statue (Marseille, France): Photogrammetry, digital cartography and construction of a thesaurus. In ISPRS - International Archives of the Photogrammetry, Remote Sensing and Spatial Information Sciences, XLII-2/WI5, pp. 1039-1046.

Teruggi S. et al. (2020). A Hierarchical Machine Learning Approach for Multi-Level and Multi-Resolution 3D Point Cloud Classification. In Remote Sensing, 12 (16), p. 2598.

\section{Autori}

Valeria Croce, Università di Pisa, valeria.croce@unifi.it

Gabriella Caroti, Università di Pisa, gabriella.caroti@unipi.it

Livio De Luca, Modèles et Simulations pour l'Architecture et le Patrimoine, UMR 3495 CNRS/MC, Marsiglia, livio.deluca@map.cnrs.fr

Andrea Piemonte, Università di Pisa, andrea.piemonte@unipi.it

Philippe Véron, LISPEN EA 7515, Arts et Métiers ParisTech, Aix-en-Provence, philippe.veron@ensam.eu

Marco Giorgio Bevilacqua, Università di Pisa, marco.giorgio.bevilacqua@unipi.it

Per citare questo capitolo: Croce Valeria, Caroti Gabriella, De Luca Livio, Piemonte Andrea, Véron Philippe, Bevilacqua Marco Giorgio (202I).Tra Intelligenza Artificiale e H-BIM per la descrizione semantica dei beni culturali: la Certosa di Pisa/Artificial Intelligence and H-BIM for the semantic description of cultural heritage: the Pisa Charterhouse. In Arena A., Arena M., Mediati D., Raffa P. (a cura di). Connettere. Un disegno per annodare e tessere. Linguaggi Distanze Tecnologie. Atti del $42^{\circ}$ Convegno Internazionale dei Docenti delle Discipline della Rappresentazione/Connecting. Drawing for weaving relationship. Languages Distances Technologies. Proceedings of the $42^{\text {th }}$ International Conference of Representation Disciplines Teachers. Milano: FrancoAngeli, pp. 608-625 


\title{
Artificial Intelligence and H-BIM for the Semantic Description of Cultural Heritage: the Pisa Charterhouse
}

\author{
Valeria Croce \\ Gabriella Caroti \\ Livio De Luca \\ Andrea Piemonte \\ Philippe Véron \\ Marco Giorgio Bevilacqua
}

Abstract

Artificial Intelligence (Al) applications to architectural heritage usher promising evolutions in the Graphic arts and design field, as increasingly automated segmentation techniques can be applied to digital and numeric models for the semantic interpretation of survey data and subsequent reconstruction of conceptual and parametric 3D representations. Increasingly automated systems for the semantic description and classification of 3D data are indeed in ever-growing demand, also in view of optimizing Scan-to-BIM processes. In this context, the present contribution describes a semi-automated methodological approach aimed at building semantically rich and intelligible representations starting from survey data. This approach features two core foundations: firstly, the classification and subsequent propagation of architectural types, by means of Artificial Intelligence (Al) algorithms applied to the point clouds; secondly, the reconstruction, in Building Information Modelling (BIM) environment, of the detected element classes, via information transmission procedures and visual programming languages. The analysis of the proposed methodology applies to representative case studies referring to selected settings of the Pisa Charterhouse.

Keywords

semantic classification, artificial intelligence, $\mathrm{H}$-BIM, architectural heritage, point clouds.

Data acquisition

Semantic segmentation via Al

H-BIM model reconstruction

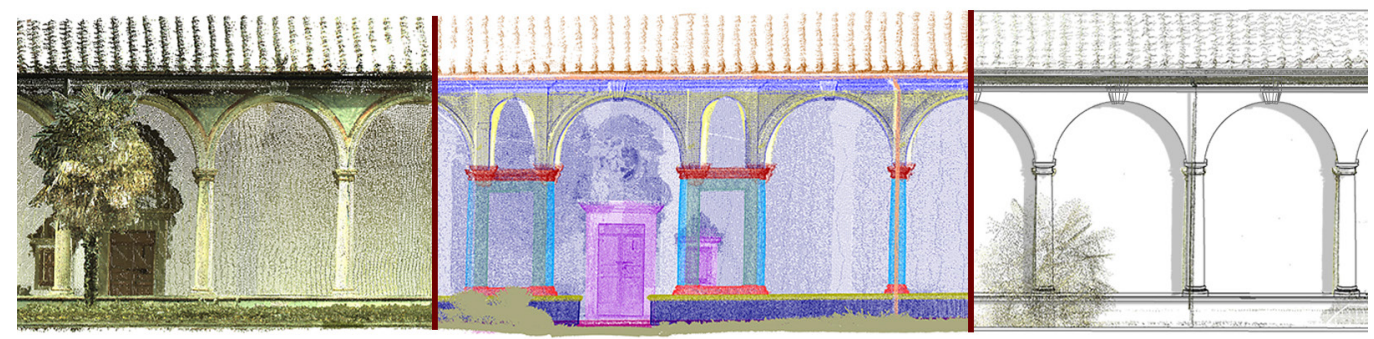




\section{Introduction}

Drafting and representation are to date making increasing use of 3D surveying for digital documentation of cultural heritage. The evolution of data collecting techniques, such as laser scanning and photogrammetry, has in fact allowed for ever wider use of point clouds and meshes as starting points in applications for preservation, enhancement and dissemination of historical and architectural heritage. Indeed, modern Scan-to-BIM processes make use of 3D data to create digital information models.

Although point clouds provide metrically verifiable input data, the reconstruction of $\mathrm{H}$-BIM (Heritage-Building Information Modelling) parametric models based on these is to date a lengthy and cumbersome process, involving complex procedures of interpreting, detecting and subsequent modelling of $3 \mathrm{D}$ elements, therefore requiring substantial user interaction. In this scenario, developments in the use of Al-based algorithms have paved the way to higher automation levels for the semantic segmentation of 3D data, i.e. partitioning survey data in groups of recurring architectural types (e.g. wall, floor, vault, column, roof etc.), detected by means of shared geometric and colorimetric features.

Increasingly automated procedures of semantic segmentation could allow for more effective characterization and description of the survey scene, by adding semantic, i.e. related to direct object acquaintance, attributes.

In dealing with this issue, the current investigation aims at describing a semi-automated approach to reconstruct intelligible representations starting from 3D survey data, also in view of the optimization of Scan-to-BIM processes. The proposed methodology refers to buildings with recurring architectural elements, and includes (fig. I):

- Semi-automated detection, classification and subsequent propagation of typological elements, by means of Al algorithms;

- 3D reconstruction of the detected geometries, via visual programming languages implemented on BIM platforms.

Both these steps are crucial for the construction of information models, in which the 3D representation is linked to external information referring to the investigation and acquaintance of the architectural object. The proposed procedure is investigated referring to selected environments of the Pisa Charterhouse.

Fig. I. Workflow of the proposed methodological approach.

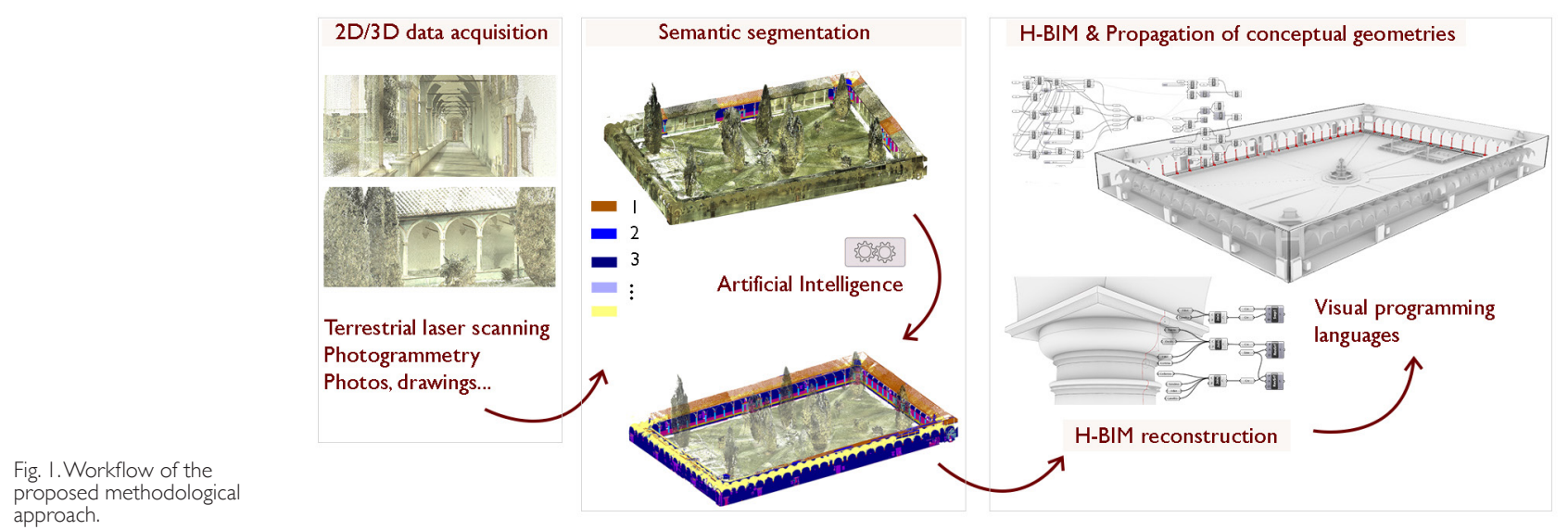

State of the art

Digital information models provide a primary supporting tool for architectural heritage preservation and protection. Through semantic annotation [Croce et al. 2020], H-BIM systems allow to link geometric representations with descriptive attributes [López et al., 20 I8, Murphy et al., 2009] involving e.g. mapping of materials, decay [Bacci et al. 20 19] and frescoed surfaces [Robleda-Prieto et al. 2016], relations between different sections of the same building [De Luca et al. 2007] or documental resources and historic information [Roussel et al. 2019]. 
As previously stated [Hichri et al. 20 I3], the process of 3D digital documentation of architectural heritage includes the following steps: i) survey data collection, ii) semantic segmentation, and iii) construction of the information model in BIM environment. Among these, ii) is the lengthiest and least automated step: designers are in fact required to interpret a massive amount of unstructured data, in order to isolate, detect and manually reconstruct the different geometries of a building, starting from a point cloud. Besides requiring sizeable user interaction, the process may also lead to significant information loss [Macher et al. 20 I7, Rocha et al. 2020].

To improve this interpretive step, by making it more objective and repeatable, increasingly automated techniques of semantic segmentation have been tested, based on Machine Learning (ML) and Deep Learning $(\mathrm{DL})$, both being Al subcategories.

Supervised ML starts off by manually annotating a section of the point cloud, and detecting features which allow for appropriate differentiation of element classes based on their properties, e.g. geometric and colorimetric features. Subsequently, the system is trained for the classification of new data, based on the detected features. In DL contexts, the system in itself detects the appropriate distinctive features, by means of multi-layer artificial neural networks.

A supervised ML algorithm, the Random Forest (RF), provided the basis for some recent investigations [Grilli et al. 20 I9; Teruggi et al. 2020], that showed that classification of 3D point clouds based on specific geometric features can be effectively applied to cultural heritage, providing distinction of recurring architectural elements.

Conversely, DL applications for cultural heritage are to date quite restricted [Matrone et al. 2020a], due on one hand to the difficulty to extend recognition of element classes to different datasets, given the morphological and typological complexity of each historical building, and on the other hand to the still inadequate availability of a critical mass of annotated data needed to train the predictive models [Matrone et al. 2020b].

For these reasons, investigation on ML-based segmentation provide to date the best outlook; anyway, proper attention to the effective use potential of 3D segmented data is still scarce, e.g. for enhancing H-BIM models. By fitting in this context, the present investigation aims at focusing on the transition from semantic point cloud to parametric H-BIM representations.

Fig. 2. The main cloister (Chiostro grande) of the Pisa Charterhouse: poin cloud acquired by laser scanner.
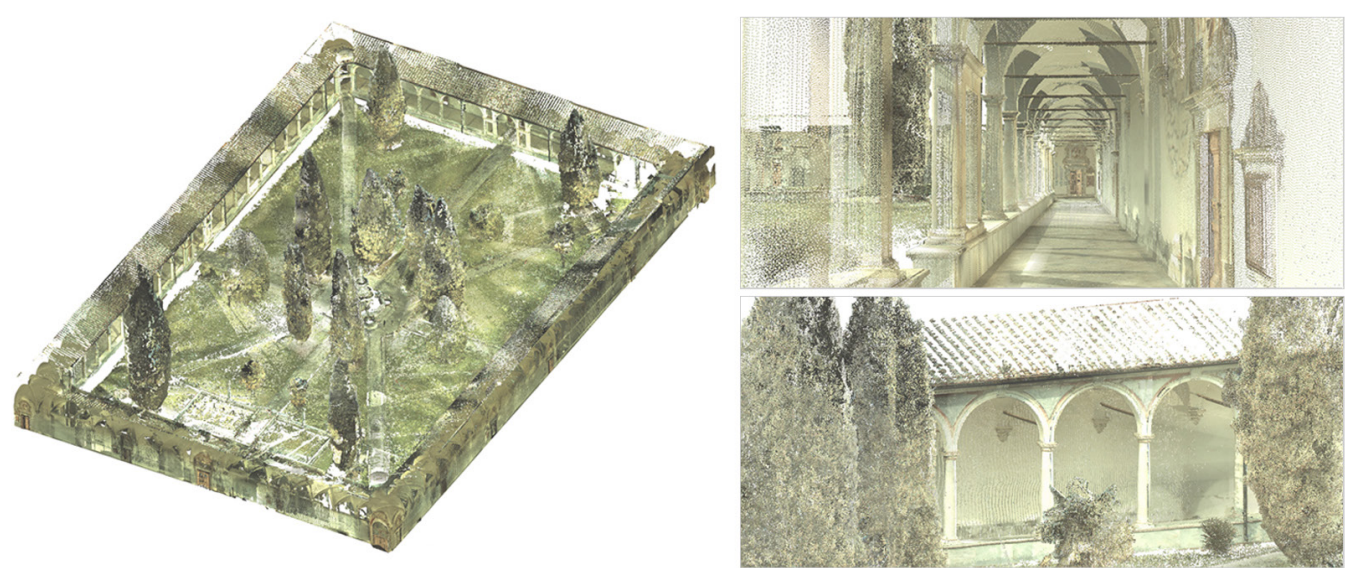

The case study of Pisa Charterhouse

Founded in 1366 on the initiative of selected patrician families, Pisa Charterhouse in Calci is one of the most prominent monastic complexes in Tuscany. Its current layout, resulting from the ceaseless expansion and renovation taking place since its very foundation, meets the typical Carthusian rules, where hermitical and coenobitical life are harmoniously fused together. Correria (low houses), courtyard of honour (main courtyard), church and cenoby 


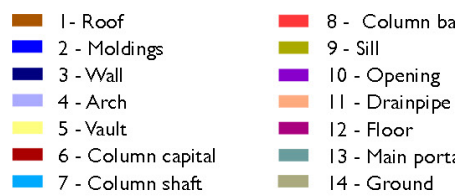

7 - Column shaft

Fig. 3. Classification of the identified typological elements starting from survey data. The 'training set'.

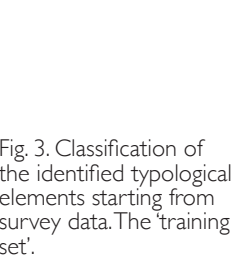

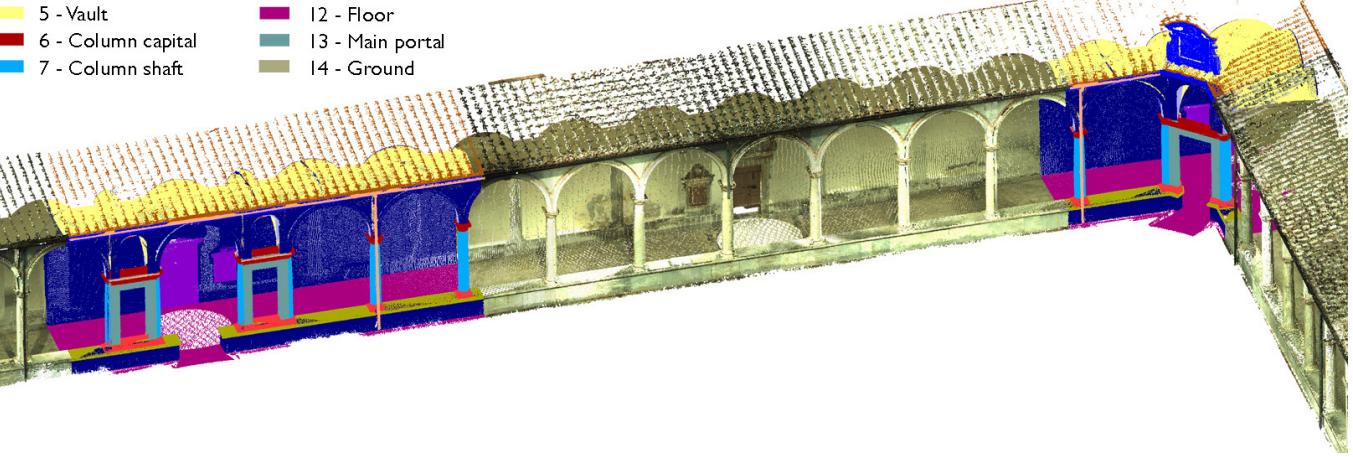

define a progressive ascent towards the desertum and the heart of the complex: the cloister of the Fathers.

The construction of the cloister began in 1375, when the first cell, intended for the prior, was first built, with works continuing until 1384.

During the $17^{\text {th }}$ century, major modernization works took place, mainly to alleviate excessive humidity in the cells. To these purposes, interventions included raising the floor of the cells and the colonnade, along with a general redesigning of the cloister [Manghi 1910].

Eighty marble columns, punctuating the perimeter of the cloister, support the cross-vault system of the ambulacrum, whose floors feature white and blue marble tiles; four Venetian windows break the succession of the columns marking the two main axes of the composition system; dry paintings, depicting holy scenes and iconographies of the Saints, grace the access doors of the cells; at the center of the cloister, the monumental, highly ornamented stone fountain supplements the overall visual impact.

No other remarkable modifications of the cloister have taken place since then, even on occasion of the major renovation works promoted by Prior Maggi in late $18^{\text {th }}$ century, which have substantially shaped the current layout of the whole complex.

Starting in late $19^{\text {th }}$ century through mid-20 th century, only minor paint works have taken place, at first to uniform plaster appearance and eventually for ordinary maintenance purposes [Benassi 2005].

Following its dissolution by the order Motherhouse in Grenoble, in 1962 the monk community began to abandon the Charterhouse, which was subsequently allocated for different museum activities.

Since 1972, in fact, the complex hosts the Nazional Museum of the Calci Monumental Charterhouse (National Museum of the Monumental Calci Charterhouse), controlled by the Italian Ministry for Cultural Heritage and Activities and for Tourism (Ministry of Culture

Verticality $(r=0.3 \mathrm{~m})$

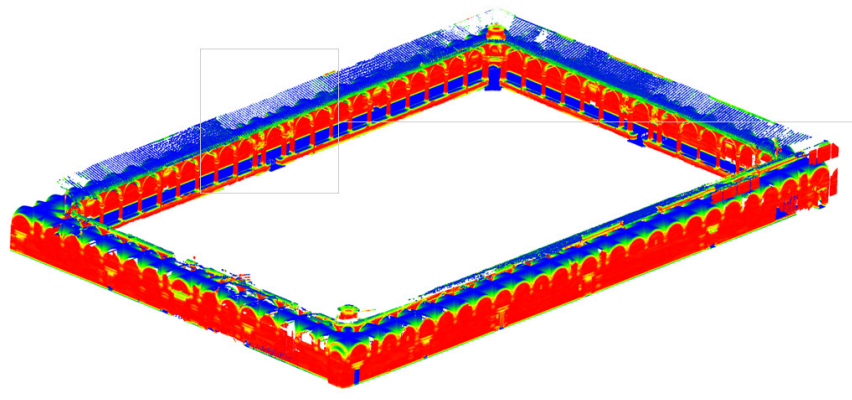
$25 \mathrm{~m}$

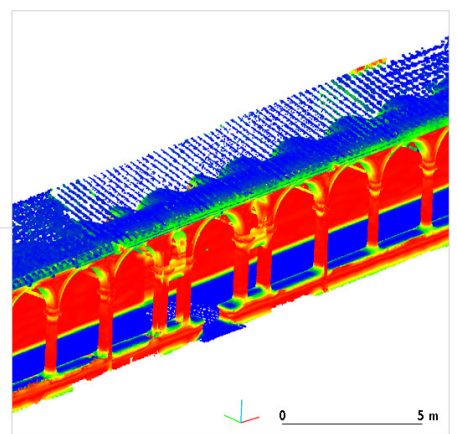




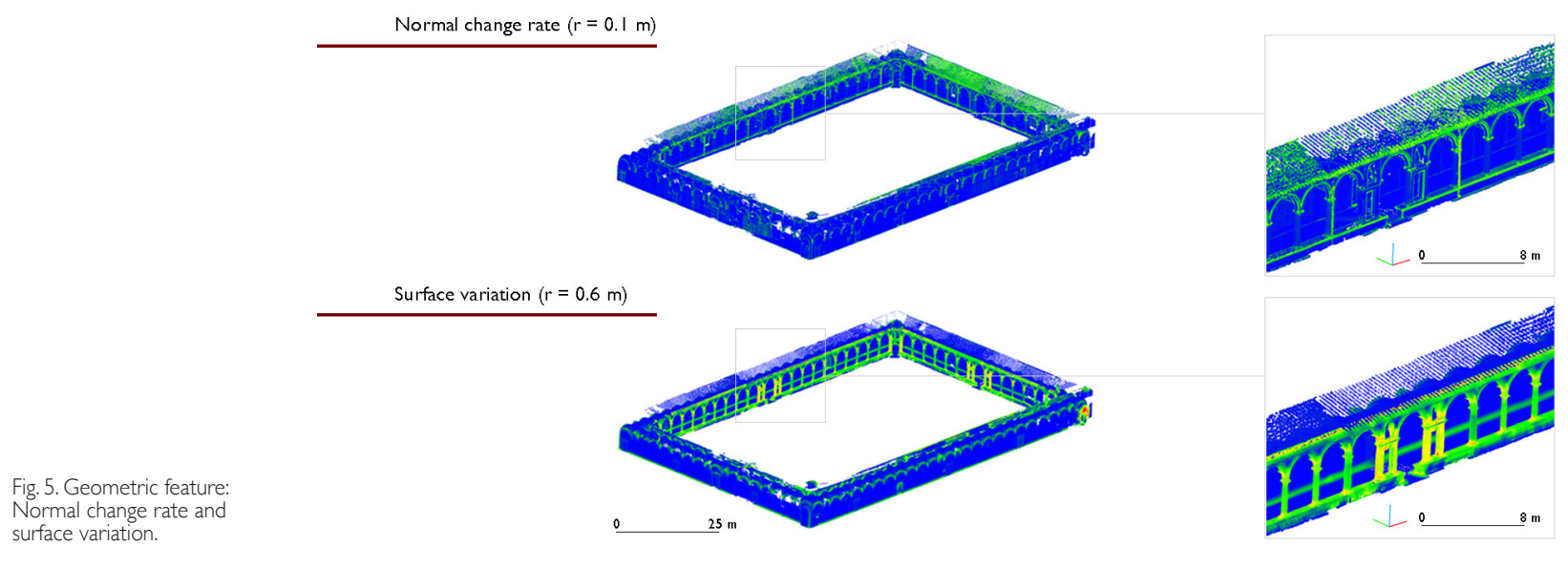

- MiBACT), and, since 1978, the Natural History Museum of the University of Pisa (Pisa University Museum of Natural History).

Since 2018, the University of Pisa has provided financial backing for a multidisciplinary research project aimed at the preservation, restoration and enhancement of the whole complex, to which the current investigation relates (fig. 2).

The current work stems from the consideration that, in the morphological and constructive complexity of historical buildings, some recurring architectural typologies and shapes are still recognizable. This allows for effective differentiation and, as a result, representation by reconstructing their 'shape grammar'.

The process of semantic segmentation is in fact the very one that led Vitruvius and other major essayists to investigate, and pass on, the typical proportions of architectural orders, thus codifying languages and models of classical architecture.

In the proposed methodological approach:

a) firstly, semantic segmentation of 3D datasets is performed, by means of Al-derived algorithms of supervised learning;

b) secondly, point clouds carrying the partitions for classes of typological elements (e.g. wall, column, floor, roof etc.) are exploited to generate and more effectively manage $\mathrm{H}$-BIM models.

In step a), classes are identified by annotating point cloud portions. This operation, along with the proper feature selection, allows for providing the learning system with an adequate number of annotated samples for the subsequent correct classification of the remaining part of the dataset.

In the supervised ML approach, features are from time to time identified and selected, based on the related case study. They may be:

- colorimetric, i.e. relating to colour data associated to each 3D point;

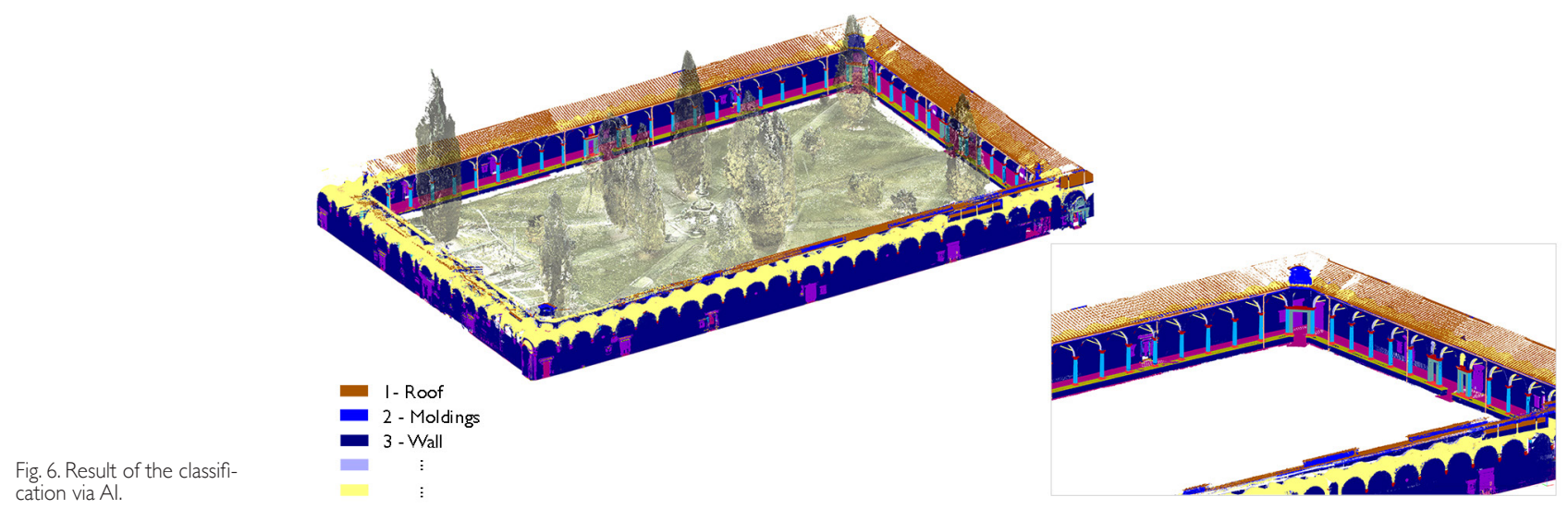


Fig. 7. Segmented point cloud import. Visualization of the class 'vaults'.
- geometric, i.e. providing a description of mutual spatial layout of cloud points. In a given neighbourhood of each 3D point, it is possible to extract geometric features such as linearity, planarity, sphericity, surface variation and so on. The methodology of feature extraction and selection has already been documented [Croce et al. 2021 ; Grilli, Farella et al. 2019]. These input data provide the basis for the construction of a predictive model, allowing to associate a semantic label to the remaining, unannotated point cloud portions.

This procedure is performed by means of a RF classifier, ultimately yielding semantically rich 3D data, in which it is possible to detect, recognize and therefore isolate each and every included architectural element. In order to validate the ML model as achieved, previsions of the classifier are eventually checked against the actual destination class.

Al-based semantic segmentation allows for custom partitioning of the initial survey data based on the represented object; in other worlds it is possible to separately process each element class. For phase b), therefore, the semantically annotated point cloud provides the basis for the reconstruction of H-BIM models composed of families of parametric elements, created class by class.

This is possible by previously defining ideal conceptual geometries for each element category, based on proportional and building rules as derived from historical sources, i.e. identifying the elementary entities (atoms) and formalizing architectural primitives on which the representation is based [De Luca et al. 2007]. As a result, the geometric nature of the elements can be reconstructed, the original planned shape is interpreted and, eventually, a reference geometry is identified and modelled for each class (parametric family).

Upon completion of the process, visual programming techniques allow for propagation and dimensional comparison of repetitive elements.
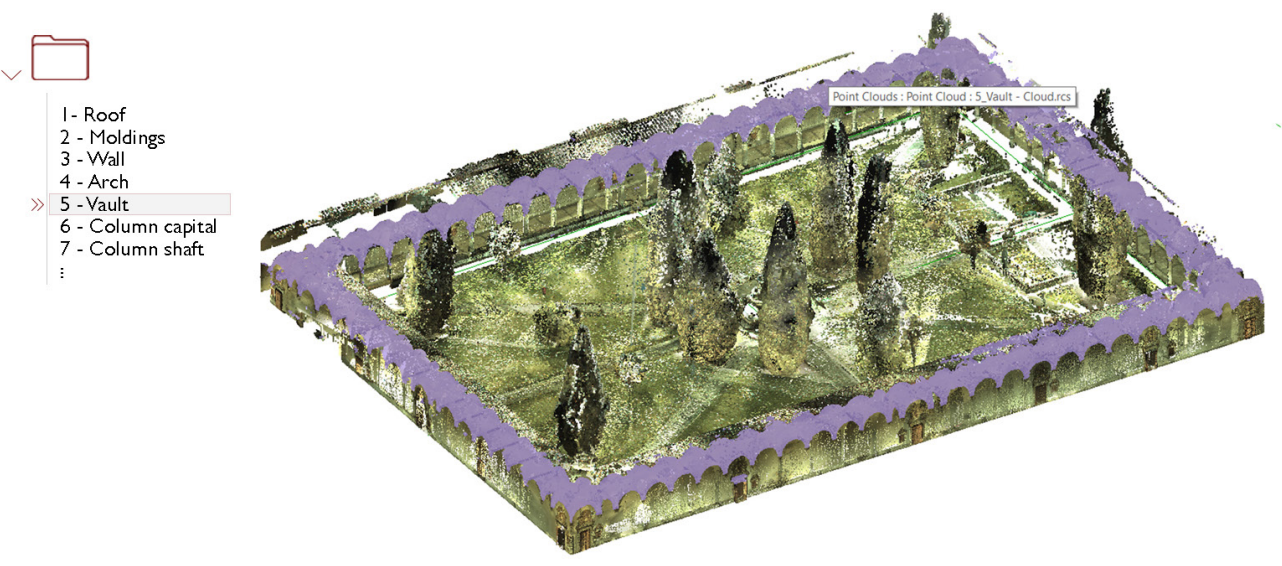

\section{Results}

The heritage of the Charterhouse is essential for the first significative tests of the proposed methodology. In fact, here the spaces are laid out in accord with Carthusian practices and customs, which entail massive repetition of archetypal elements: the main cloister, the lesser cloister, the cells of the Fathers and the church, with colonnades, galleries and frescoed vaults.

For the main cloister of the Pisa Charterhouse, starting from the initial cloud, I4 element classes, as per architectural treatises, are manually annotated on a small portion (fig. 3). Geometric features are then extracted and selected (figs. 4, 5).

The manual annotation of the so-called 'training set' allows to train a RF classifier, so as to extend the semantic segmentation to the whole cloister dataset. Fig. 6 shows the classification result, that provides the initial data for subsequent construction of the H-BIM model. Each element class, upon segmentation and isolation from the complete cloister dataset, is separately imported in H-BIM environment (fig. 7).

For each class, the reconstruction of the conceptual parametric shape follows the formalization approach [De Luca et al. 2007] based on: interpretation of any knowledge referring to 
the shape; detection of the modelling methods; identification of the relations between the different shape constituents (figs. 8, 9).

Upon defining an ideal conceptual geometry, the latter is propagated to other point cloud sections identified as belonging to the same class, according to a reconstruction approach based on visual programming languages.

When applied to each category, this approach allows to achieve the parametric virtual model, a 'digital twin' which can be augmented with information on materials, restoration and consolidation interventions, thermal and energy performances, and so forth.
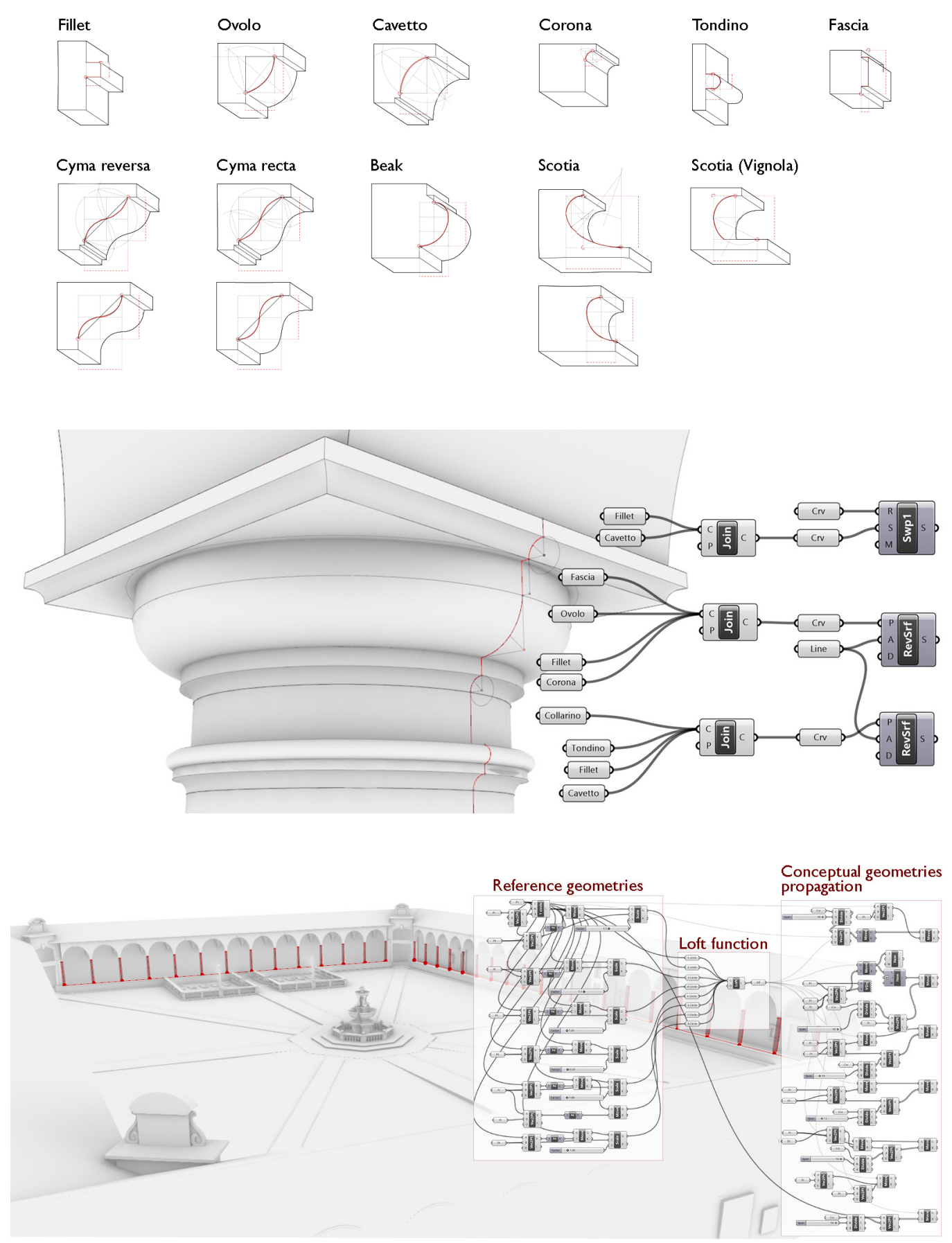


\section{Conclusions}

Al techniques applied to cultural heritage lay the foundations for innovative ways of interpreting, recognizing and representing geometric data derived from surveying, both 2- and 3-D, establishing a stronger formal and ontological link between metric data and integrated digital models such as $\mathrm{H}$-BIM, for more effective documentation of the built heritage (figs. $10,11)$.

Further testing will aim at improving the construction of the digital twin and extending the proposed methodology to other datasets, applying the same approach to other case studies, involving historical buildings and cultural heritage from different construction periods or under different preservation conditions, so to assess the specificity of each new context. Lastly, Al applications for semantic mapping of decay levels or surface material restitution from 2D/3D survey data are currently investigated as further development of the present work.

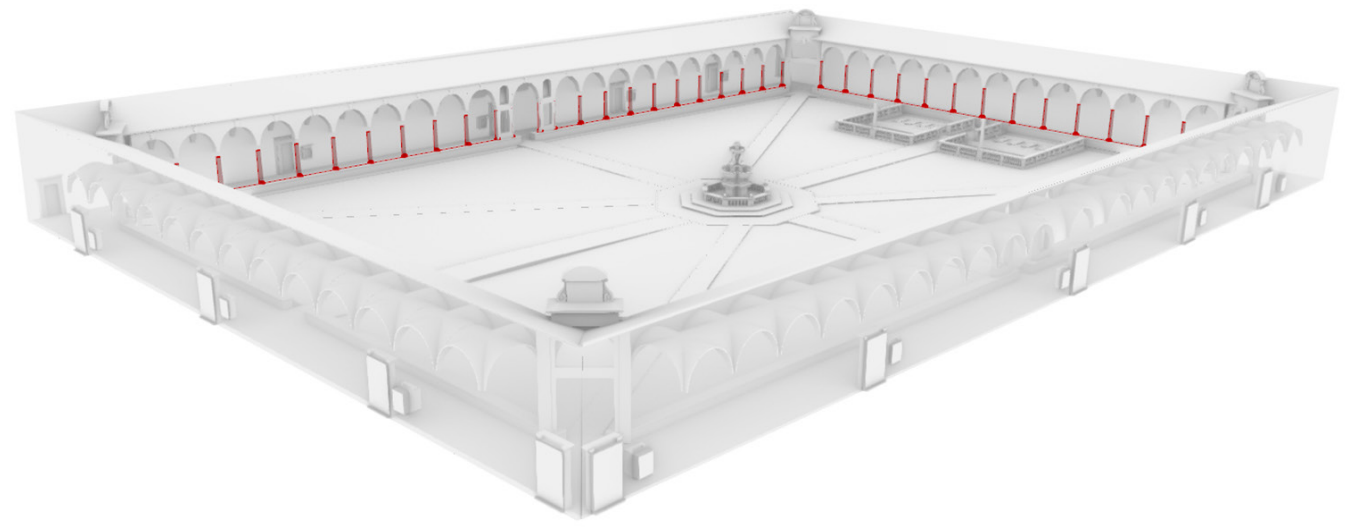

\section{Acknowledgement}

This study is part of the project Studi conoscitivi e ricerche per la conservazione e la valorizzazione del Complesso della Certosa di Calci e dei suoi Poli Museali, promoted by the University of Pisa. We therefore thank all the researchers and collaborators involved in the project. The research is partly funded by the Université Franco-Italienne, within the framework of the Vinci 2019 project - Mobility grants for co-supervised Ph.D. theses, which promotes collaboration between Italian and French research units.

\section{References}

Bacci G. et al. (2019). HBIM methodologies for the architectural restoration. The case of the ex-church of San Quirico all'Olivo in Lucca, Tuscany. In ISPRS - International Archives of the Photogrammetry, Remote Sensing and Spatial Information Sciences, XLII-2/ WII, pp. $121-126$.

Benassi L. (2005). Il chiostro grande della Certosa di Calci: storia, paesaggio, architettura. Pisa: Primula Multimedia, 2005, pp. 25-29.

Croce V. et al. (2020). Semantic annotations on heritage models: 2D/3D approaches and future research challenges. In ISPRS International Archives of the Photogrammetry, Remote Sensing and Spatial Information Sciences, XLIII-B2-2020, pp. 829-836.

Croce V. et al. (202I). From the Semantic Point Cloud to Heritage-Building Information Modeling: A Semiautomatic Approach Exploiting Machine Learning. In Remote Sensing, I3 (3), p. 46 I.

De Luca L.,Véron P., Florenzano M. (2007). A generic formalism for the semantic modeling and representation of architectural elements. In The Visual Computer, 23 (3), pp. I8I-205.

Grilli E. et al. (2019). Geometric features analysis for the classification of Cultural Heritage point clouds. In ISPRS - International Archives of the Photogrammetry, Remote Sensing and Spatial Information Sciences, XLII-2N I 5, pp. 54I-548. 
Grilli E., Özdemir E., Remondino F. (2019). Application of machine and deep learning strategies for the classification of heritage point clouds. In ISPRS - International Archives of the Photogrammetry, Remote Sensing and Spatial Information Sciences, XLII-4/ WI8, pp. 447-454.

Hichri N. et al. (20 I3). From point cloud to BIM: A survey of existing approaches. In ISPRS - International Archives of the Photogrammetry, Remote Sensing and Spatial Information Sciences, XL-5/W2, pp. 343-348.

López F. et al. (20 I8). A Review of Heritage Building Information Modeling (H-BIM). In Multimodal Technologies and Interaction, 2 (2), p. 21.

Macher H., Landes T., Grussenmeyer P. (2017). From Point Clouds to Building Information Models: 3D Semi-Automatic Reconstruction of Indoors of Existing Buildings. In Applied Sciences, 7 ( I0), p. 1030.

Manghi A. (19|0). II Gran Chiostro della Certosa di Pisa. Pisa: Mariotti.

Matrone F., Grilli E. et al. (2020). Comparing Machine and Deep Learning Methods for Large 3D Heritage Semantic Segmentation. In ISPRS International Journal of Geo-Information, 9 (9), p. 535.

Matrone F., Lingua A. et al. (2020). A benchmark for large-scale heritage point cloud semantic segmentation. In ISPRS - International Archives of the Photogrammetry, Remote Sensing and Spatial Information Sciences, XLIII-B2-2020, pp. I 4I 9 - I 426.

Murphy M., McGovern E., Pavia S. (2009). Historic building information modelling (HBIM). In ISPRS - International Archives of the Photogrammetry, Remote Sensing and Spatial Information Sciences, 27 (4), pp. 3 I I-327.

Robleda P. G. et al. (20 I 6). Computational vision in UV-mapping of textured meshes coming from photogrammetric recovery: Unwrapping frescoed vaults. In ISPRS - International Archives of the Photogrammetry, Remote Sensing and Spatial Information Sciences, XLI-B5, pp. 39I-398.

Rocha G. et al. (2020). A Scan-to-BIM Methodology Applied to Heritage Buildings. In Heritage, 3 ( I), pp. 47-67.

Roussel R. et al. (2019). A digital diagnosis for the "autumn" statue (Marseille, France): Photogrammetry, digital cartography and construction of a thesaurus. In ISPRS - International Archives of the Photogrammetry, Remote Sensing and Spatial Information Sciences, XLII-2/WI5, pp. 1039-1046.

Teruggi S. et al. (2020). A Hierarchical Machine Learning Approach for Multi-Level and Multi-Resolution 3D Point Cloud Classification. In Remote Sensing, 12 (16), p. 2598.

\section{Autohrs}

Valeria Croce, Università di Pisa, valeria.croce@unifi.it

Gabriella Caroti, Università di Pisa, gabriella.caroti@unipi.it

Livio De Luca, Modèles et Simulations pour l'Architecture et le Patrimoine, UMR 3495 CNRS/MC, Marsiglia, livio.deluca@map.cnrs.fr Andrea Piemonte, Università di Pisa, andrea.piemonte@unipi.it

Philippe Véron, LISPEN EA 75।5, Arts et Métiers ParisTech, Aix-en-Provence, philippe.veron@ensam.eu

Marco Giorgio Bevilacqua, Università di Pisa, marco.giorgio.bevilacqua@unipi.it

To cite this chapter. Croce Valeria, Caroti Gabriella, De Luca Livio, Piemonte Andrea, Véron Philippe, Bevilacqua Marco Giorgio (202I). Tra Intelligenza Artificiale e H-BIM per la descrizione semantica dei beni culturali: la Certosa di Pisa/Artificial Intelligence and H-BIM for the semantic description of cultural heritage: the Pisa Charterhouse. In Arena A., Arena M., Mediati D., Raffa P. (a cura di). Connettere. Un disegno per annodare e tessere. Linguaggi Distanze Tecnologie. Atti del $42^{\circ}$ Convegno Internazionale dei Docenti delle Discipline della Rappresentazione/Connecting. Drawing for weaving relationship. Languages Distances Technologies. Proceedings of the $42^{\text {th }}$ International Conference of Representation Disciplines Teachers. Milano: FrancoAngeli, pp. 608-625. 